\title{
Определение атрибутов потребительской ценности медицинских услуг
}

\section{Елена Сологуб}

Дальневосточный федеральный университет, г. Владивосток, Россия

\author{
Информация о статье \\ Поступила в редакиию: \\ 12.03.2020 \\ Принята \\ к опубликованию: \\ 13.04.2020 \\ УДК 339.138 \\ JEL M31
}

\begin{abstract}
Ключевые слова:
потребительская ценность, атрибуты потребительской ценности, медицинская услуга, коммерческая медицина, структура потребительской ценности, оценка потребительской ценности, медицинский маркетинг, контент-анализ, глубинное интервью
\end{abstract}

\footnotetext{
Keywords:

consumer value, attributes of consumer value, medical service, commercial medicine, structure of consumer value, assessment of consumer value, medical marketing, content analysis, detailed interview
}

\begin{abstract}
Аннотация
В работе предложен методический подход к определению атрибутов потребительской ценности медицинской услуги. Представлены результаты, полученные в рамках четырёх этапов исследования: контент-анализа тематических источников по сочетающимся словам, группировки и соотнесении атрибутов, а также глубинного интервью с экспертами из медицинской сферы.
\end{abstract}

\section{Definition of Attributes for Medical Services Consumer Value}

Elena Sologub

\section{Abstract}

This investigation introduces a methodological approach which allows to define the attributes for medical services consumer value. The study concentrates on the primary need to determine the medical services consumer value.

The proposed methodological approach to determine the attributes for medical services consumer value contains four stages, namely: 1) content analysis; 2) attributes grouping; 3) attributes systematization 4) detailed interview with experts. The content analysis of topical texts was conducted using the harmonious words found in contemporary Russian and foreign studies. More than 4000 various mentioned attributes for the medical service consumer value were analyzed. All attributes were then grouped by the type of consumers' benefits and costs. The medical service consumer value attributes were arranged in accordance with the elements of $7 P$ marketing mix. The frequency of the mentioned attributes for medical service consumer value was calculated based on the results of the content analysis and detailed interview with the experts from the medical sector. The results of the investigation are important for assessing the medical service consumer value. 


\section{Введение}

В современных условиях усиливается роль ценностноориентированного подхода к развитию предприятий, в том числе, в сфере здравоохранения. Несмотря на то, что потребительская ценность является ключевым аспектом в маркетинге, который подразумевает под собой «создание, продвижение, предоставление и мониторинг покупательской ценности», проблемы оценки потребительской ценности медицинских услуг, определения структуры выгод и затрат, формируемых медицинскими центрами, остаются малоизученными [1].

Американская ассоциация маркетинга полагает, что создание и обмен ценностями между субъектами маркетинговой деятельности - это основная функция, определяющая сущность данной деятельности [2].

В научной среде существует дискуссия в отношении того, что включает в себя потребительская ценность.

Ряд исследователей в структуру потребительской ценности товара/услуги включают преимущественно выгоды, получаемые потребителем [3-7].

Ф. Котлер, Г. Армстронг, Дж. Сондерс, В. Вонг [8], Д. Джоббер [9], С. Брок, М. Колгейт [10], Ю. Ванг, Х. Поло, Р. Чи, Ю. Янг [11], Р. Бестр [12], С. Слэйт [13], а также М. Дубинина [14], А. Зверева [15], А. Юдаев [16] уделяют внимание затратам потребителя, как равноправным составляющим потребительской ценности товара/услуги, наряду с выгодами потребителей.

Таким образом, можно выделить две основные позиции авторов в отношении составляющих элементов (атрибутов) потребительской ценности товара/услуги:

- потребительская ценность складывается из различных выгод, получаемых потребителями;

- потребительская ценность включает в себя как выгоды, так и затраты потребителей.

Мы придерживаемся классического маркетингового подхода и рассматриваем потребительскую ценность как соотношение выгод и затрат потребителя. В этом случае учитывается два момента: психологическая оценка степени соответствия товаров требованиям потребителей и оценка затрат на приобретение товара.

Основная сложность и проблема выделения атрибутов потребительской ценности состоит в том, что она включает в себя не только экономические, т.е., поддающиеся измерению аспекты, но и психологические, эмоциональные элементы, являясь многомерной структурой. На наш взгляд, недостаточно внимания уделяется затратам, среди которых в основном учитываются финансовые затраты потребителей, а эмоциональные, физические, временные остаются неохваченными. Вопросы определения атрибутов потребительской ценности тесно переплетаются с проблемой соотношения рационального и нерационального в поведении потребителей (теория перспектив, парадигма «эвристик и сдвигов» $[17,18]$.

Изучение атрибутов потребительской ценности представляется крайне важным по причине того, что потребительская ценность меняется во времени. Предприятия, которые не учитывают происходящие изменения, в услови- 
ях рынка могут существенно ослабить свои конкурентные позиции. Не владея информацией о структуре потребительской ценности, о её атрибутивных характеристиках, предприятия не смогут сформировать ценность, за которую потребитель готов будет платить максимально возможную цену. При этом изменение и замена атрибутов, входящих в структуру структуры потребительской ценности влечёт за собой изменение ценностного предложения компании, и, соответственно, модели построения бизнеса компании.

Слабо изучена отраслевая специфика формирования потребительской ценности товаров/услуг. В частности, для активно развивающегося в нашей стране рынка медицинских услуг, оказываемых коммерческими медицинскими центрами, важно понимание атрибутов потребительской ценности медицинской услуги. Имеющиеся научные наработки не дают точного представления о том, каким образом определяются атрибуты потребительской ценности медицинских услуг и на основании чего коммерческие медицинские организации могут формировать ценностное предложение, включающее набор атрибутов потребительской ценности.

Целью данного исследования является обоснование и предложение методического подхода к определению конкретных атрибутов потребительской ценности медицинской услуги, что позволит осуществить качественную оценку и сформировать предложение, характеризующееся максимальной ценностью для потребителя.

Задачи исследования:

- реализация всех этапов, как составных частей методического подхода к определению атрибутов потребительской ценности медицинских услуг;

- выявление конкретных атрибутов потребительской ценности медицинских услуг.

Объектом исследования являются услуги, оказываемые коммерческими медицинскими центрами; предметом - атрибуты потребительской ценности медицинской услуги.

\section{Методы и результаты исследования}

На сегодняшний день, учёные и представители бизнес-среды осознают необходимость не просто учёта потребительских предпочтений и ценностных ориентаций клиентов, но и особую значимость вовлечения потребителей в процесс создания ценности. Для рынка медицинских услуг также характерным становится то, что потребитель уже является сопроизводителем услуги. Значение ценностного подхода сложно переоценить. Медицинским организациям необходимо понимать, что наиболее важно для потребителя: чем он может пожертвовать, а что является обязательным условием, способствующим обращению в тот или иной медицинский центр. В связи с активным развитием рынка медицинских услуг в России и высокой востребованностью их у населения, появляются новые медицинские центры, оказывающие схожие услуги и вынужденные конкурировать за клиента, у которого ещё есть альтернатива пользования бесплатной медициной в рамках обязательного медицинского страхования. 
Учёт атрибутов, формирующих потребительскую ценность медицинской услуги, напрямую влияет на удовлетворение потребителей и повышение их лояльности к конкретному медицинскому центру.

Несмотря на наличие разнообразных методов, направленных на оценку потребительской ценности, не существует единой унифицированной методики, позволяющей произвести оценку потребительской ценности товаров/услуг на любых рынках [19], отсутствует методический подход, который наиболее применим для рынка медицинских услуг. Атрибуты потребительской ценности медицинской услуги, встречающиеся в тематических источниках, не систематизированы.

Специализированный рынок медицинских услуг требует использования оптимальной комбинации методов и инструментов, способствующих выявлению атрибутов потребительской ценности медицинской услуги. Для решения обозначенной проблемы разработан авторский подход к определению атрибутивных характеристик потребительской ценности медицинской услуги. Данный подход предполагает реализацию нескольких этапов:

1) проведение контент-анализа научных публикаций;

2) группировка атрибутивных характеристик;

3) соотнесение атрибутивных характеристик с элементами комплекса маркетинга 7Р в соответствии с видами выгод и затрат потребителей;

4) глубинное интервью экспертов для детализации атрибутивных характеристик.

На рис. 1 представлены методы, используемые на каждом из этапов исследования.

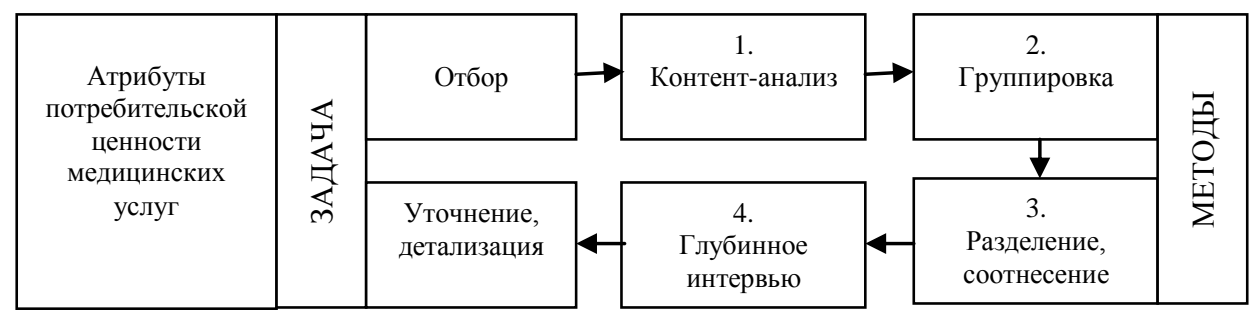

Puc. 1. Методы и этапы исследования

Источник: составлено автором

Метод контент-анализа позволяет определить перечень характеристик, в последующем сгруппировав их по наиболее часто встречающимся обобщённым выражениям, отражающим суть той или иной характеристики.

В научной, тематической литературе редко можно встретить формулировку «атрибуты потребительской ценности медицинской услуги».

При проведении контент-анализа мы учитывали сочетаний разных слов, употребляемых в российских и зарубежных англоязычных источниках, опубликованных в период с 2000 по 2020 гг. (рис. 2).

Выбор сочетаний слов, представленных на рис. 2, представляет собой атрибуты потребительской ценности медицинской услуги и обусловлен наиболее частым упоминанием в различных источниках. 


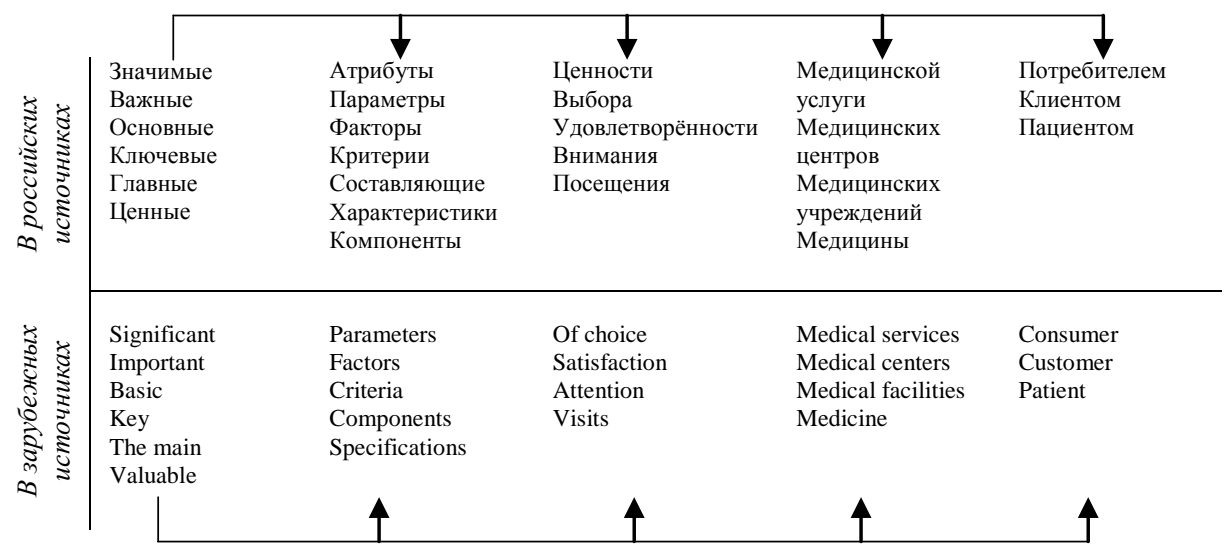

Puc. 2. Сочетания слов, используемых при контент-анализе и определяющих возможные атрибуты потребительской ценности

Источник: составлено автором

В ходе исследования был произведен анализ информационного массива: научных и обзорных статей, результатов эмпирических зарубежных и российских исследований, отзывов и упоминаний о медицинских услугах и медицинских центрах в социальных сетях и пр. с учётом морфологии. В табл. 1 представлены источники, из которых собиралась информация о конкретных атрибутах.

Таблийа 1

Источники определения атрибутивных характеристик потребительской ценности медицинских услуг в зависимости от аудитории

\begin{tabular}{|c|c|c|c|}
\hline $\begin{array}{c}\text { Клиенты медицинских } \\
\text { центров }\end{array}$ & $\begin{array}{c}\text { Сотрудники меди- } \\
\text { цинских центров } \\
\text { (врачи, обслужи- } \\
\text { вающий персонал) }\end{array}$ & $\begin{array}{c}\text { Эксперты (представи- } \\
\text { тели органов управле- } \\
\text { ния в системе здраво- } \\
\text { охранения, руководи- } \\
\text { тели медицинских уч- } \\
\text { реждений) } \\
\end{array}$ & $\begin{array}{c}\text { Учёные, исследова- } \\
\text { тели сферы оказа- } \\
\text { ния медицинских } \\
\text { услуг }\end{array}$ \\
\hline $\begin{array}{l}\text { Отзывы в социальных } \\
\text { сетях, на сайтах меди- } \\
\text { цинских центров, на спе- } \\
\text { циализированных интер- } \\
\text { нет-ресурсах; } \\
\text { новостные ленты; } \\
\text { тематические порталы и } \\
\text { форумы. }\end{array}$ & $\begin{array}{l}\text { Публикации в СМИ, в } \\
\text { том числе результаты } \\
\text { интервью; } \\
\text { паблики в социальных } \\
\text { сетях; } \\
\text { сайты медицинских } \\
\text { учреждений. }\end{array}$ & $\begin{array}{l}\text { Статьи в СМИ; } \\
\text { сайты медицинских учре- } \\
\text { ждений; } \\
\text { официальные сайты госу- } \\
\text { дарственных и муници- } \\
\text { пальных } \quad \text { учреждений } \\
\text { управления в системе } \\
\text { здравоохранения; } \\
\text { информационные интер- } \\
\text { нет-порталы. }\end{array}$ & $\begin{array}{l}\text { Российские и зарубеж- } \\
\text { ные интернет-базы } \\
\text { научных статьей; } \\
\text { отчёты о проведённых } \\
\text { профильных исследо- } \\
\text { ваниях; } \\
\text { монографии, диссерта- } \\
\text { ции, учебные издания. }\end{array}$ \\
\hline
\end{tabular}

Источник: составлено автором

Атрибуты потребительской ценности медицинской услуги определялись исходя из их упоминания представителями различных аудиторий (не только непосредственными клиентами, но и сотрудниками медицинских учреждений, экспертами в области здравоохранения, учёными).

База данных источников для анализа была отобрана с использованием поисковых ресурсов в сети Интернет путем комбинации запросов с помощью набора словосочетаний, представленных на рис. 2. К примерам таких сочета- 
ний слов можно отнести «факторы успеха медицинской организации», «показатели качества медицинской услуги», «критерии выбора медицинских центров потребителями», «факторы удовлетворённости потребителей», «параметры выбора медицинского учреждения», «критерии важности для пациентов» и пр.

Результаты обрабатывались с использованием автоматизированной системы Медиалогия и программы Microsoft Excel.

Было зафиксировано около 4000 упоминаний атрибутов потребительской ценности медицинских услуг. В результате сформирован перечень, включающий 86 атрибутов, касающихся выгод, получаемых потребителями (табл. 2) и 17 атрибутов, относящихся к затратам потребителя с учётом частоты их упоминания (табл. 3).

Таблица 2

Атрибуты потребительской ценности медицинской услуги по выгодам потребителей в соответствии с частотой их упоминания в источниках, полученные в результате контент-анализа

\begin{tabular}{|c|c|}
\hline $\begin{array}{c}\text { Частота } \\
\text { упоминания }\end{array}$ & Выгоды потребителей \\
\hline \multirow{10}{*}{ 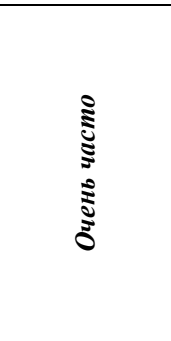 } & Вежливость персонала, доброжелательность, спокойная реакция \\
\hline & Внимание к пациентам (участие в проблемах клиентов, индивидуальный подход) \\
\hline & Наличие профессионального опыта у врача, стажа работы \\
\hline & Наличие современного оборудования \\
\hline & Приветливость, улыбчивость администраторов \\
\hline & Приём по времени (отсутствие очереди) \\
\hline & Применение современных медицинских технологий и методов лечения \\
\hline & Сарафанное радио (рекомендации родственников, друзей, знакомых) \\
\hline & Уровень квалификации, профессионализм врачей \\
\hline & Уровень чистоты помещений \\
\hline \multirow{15}{*}{ 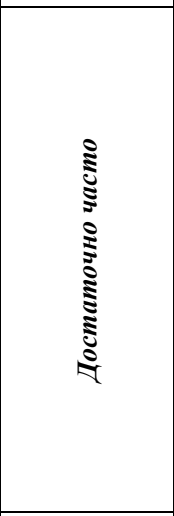 } & Бренд, положительная репутация медицинского центра \\
\hline & Доступность (получение услуг в удобное для клиента время) \\
\hline & Комплексность услуги (приём, анализы и пр. в одном месте) \\
\hline & Комфортные места ожидания, удобная мебель \\
\hline & Конкретный врач, к которому есть желание попасть на приём \\
\hline & Красивое оформление, дизайн помещений \\
\hline & Многопрофильность медицинского центра \\
\hline & Наличие реальных отзывов клиентов в сети интернет \\
\hline & Наличие узких специалистов \\
\hline & Скорость предоставления услуги (обследования/анализа) \\
\hline & Удобный режим и график работы медицинского центра \\
\hline & Удобство записи на приём \\
\hline & Уникальность оказываемой услуги (предоставляют не все медицинские центры) \\
\hline & Уровень квалификации, профессионализм среднего медицинского персонала \\
\hline & Широкий спектр оказываемых услуг \\
\hline \multirow{8}{*}{ 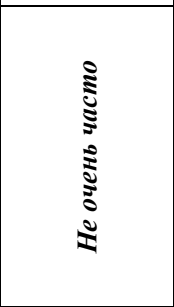 } & Возможность обслуживания и взрослых, и детей \\
\hline & Гарантии безопасности предоставляемых услуг \\
\hline & Дистанционные консультации после приема (по телефону, WhatsApp и пр.) \\
\hline & Доступная/низкая цена \\
\hline & $\begin{array}{l}\text { Легкость поиска информации о медицинском центре, его врачах с помощью поисковых } \\
\text { запросов в Yandex, Google и пр. }\end{array}$ \\
\hline & Наличие парковки \\
\hline & Наличие рекламы в социальных сетях, в пабликах популярных блогеров \\
\hline & Наличие собственной лаборатории в медицинском центре \\
\hline
\end{tabular}




\begin{tabular}{|c|c|}
\hline \begin{tabular}{c|} 
Частота \\
упоминания
\end{tabular} & Выгоды потребителей \\
\hline & $\begin{array}{l}\text { Полноценность, полнота приёма (разъяснение своих действий, выполнение всех необхо- } \\
\text { димых манипуляций, предоставление полной информации) }\end{array}$ \\
\hline & $\begin{array}{l}\text { Получение желаемого результата от посещения медицинского центра (эффективность } \\
\text { лечения, точность диагноза и пр.) }\end{array}$ \\
\hline & Приятный интерьер \\
\hline & $\begin{array}{l}\text { Проведение акций, мероприятий, специальные предложения для клиентов (благотвори- } \\
\text { тельные акции, тематические вечеринки, праздники, утренники для детей и пр.) }\end{array}$ \\
\hline & Соответствие цены и качества \\
\hline & Удобная, понятная навигация по территории медицинского центра \\
\hline & Удобное расположение медицинского центра вблизи дома/работы \\
\hline & Удобное расположение медицинского центра в центральных районах города \\
\hline & $\begin{array}{l}\text { Хорошо организованная работа Call-центра (оперативность, компетентность, вежливость } \\
\text { при ответах на звонки и сообщения) }\end{array}$ \\
\hline \multirow{24}{*}{$\frac{2}{3}$} & Аккуратный, ухоженный внешний вид сотрудников, единая форма у персонала \\
\hline & Возможность влиять на характеристики оказываемых услуг \\
\hline & Возможность вызова врача на дом \\
\hline & Возможность перекусить \\
\hline & $\begin{array}{l}\text { Грамотное управление медицинским центром руководством (отсутствие видимых про- } \\
\text { блем) }\end{array}$ \\
\hline & Длительный период работы медицинского центра на рынке \\
\hline & Доступ к питьевой воде \\
\hline & Наличие видеорекламы о медицинском центре и его врачах в сети интернет \\
\hline & Наличие дневного стационара \\
\hline & Наличие информации рекламного характера в электронных СМИ \\
\hline & Наличие контекстной, баннерной, всплывающей рекламы в сети интернет \\
\hline & Наличие нескольких способов оплаты (включая безналичный расчёт) \\
\hline & Наличие ночного стационара \\
\hline & $\begin{array}{l}\text { Наличие программы лояльности с возможностью копить бонусы, которыми можно рас- } \\
\text { плачиваться }\end{array}$ \\
\hline & $\begin{array}{l}\text { Наличие программы лояльности с возможностью получать комплементы, приятные не- } \\
\text { материальные бонусы от медицинского центра }\end{array}$ \\
\hline & Наличие программы лояльности с накопительной скидкой \\
\hline & Наличие программы лояльности с фиксированной скидкой \\
\hline & Наличие рекламы о медицинском центре, врачах на телевидении, на радио \\
\hline & Наличие удобного сайта медицинского центра \\
\hline & Расположение вблизи остановок общественного транспорта \\
\hline & Скорость и качество постановки диагноза \\
\hline & Соответствие стоимости услуг ожиданиям клиента \\
\hline & Удалённые консультации (получение услуги дистанционно) \\
\hline & Удобный подъезд к медицинскому центру \\
\hline \multirow{15}{*}{ 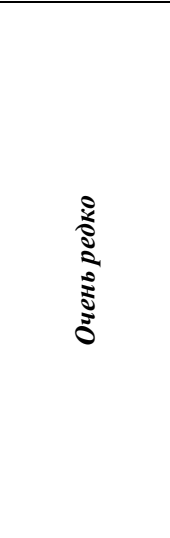 } & Готовность медицинского центра учитывать мнения и пожелания клиентов \\
\hline & Дополнительные материальные выгоды (государственная поддержка, квоты) \\
\hline & $\begin{array}{l}\text { Использование элементов дополненной и виртуальной реальности при оказании услуг } \\
\text { (3Д очки, видеосимуляторы и пр.) }\end{array}$ \\
\hline & Наличие детской комнаты \\
\hline & Наличие информации не прямого рекламного характера о медицинском центре в СМИ \\
\hline & Наличие музыкального сопровождения \\
\hline & Наличие рекламных баннеров, вывесок о медицинском центре, врачах на улицах \\
\hline & Наличие рекламы о медицинском центре, его врачах, приходящей на электронную почту \\
\hline & Наличие специализации медицинского центра по виду оказываемых услуг \\
\hline & Наличие, удобство, функциональность мобильного приложения \\
\hline & Несколько медицинских центров под одним брендом (сеть) \\
\hline & Понятная структура цены на услуги \\
\hline & Приятный запах, отсутствие запаха больницы \\
\hline & Развитая инфраструктура вблизи медицинского центра \\
\hline & Юридическая и информационная поддержка клиентов \\
\hline
\end{tabular}

Источник: составлено автором 
Частота упоминаний фиксировалась по следующим критериям:

- «очень часто» - когда параметр встречается в 40\% источников и чаще;

- «достаточно часто» - от 30 до 40\%;

-«не очень часто» - от 20 до $30 \%$;

-«редко»-10-20\%;

- «очень редко» - менее, чем в 10\% источников.

Также были получены атрибуты потребительской ценности медицинской услуги по затратам потребителя (табл. 3).

Таблий 3

Атрибуты потребительской ценности медицинской услуги по затратам потребителя в соответствии с частотой их упоминания в источниках, полученные в результате контент-анализа

\begin{tabular}{|c|c|}
\hline $\begin{array}{c}\text { Частота } \\
\text { упоминания }\end{array}$ & Затраты потребителей \\
\hline \multirow{2}{*}{ Очень часто } & Отрицательные эмоции от взаимодействия с персоналом \\
\hline & Длительное ожидание \\
\hline \multirow{5}{*}{$\begin{array}{l}\text { Достаточно } \\
\text { часто }\end{array}$} & Завышенная стоимость услуг \\
\hline & Дискомфорт от нахождения в медицинском центре \\
\hline & Переплата за дополнительные ненужные услуги \\
\hline & Отсутствие возможности комплексного обслуживания \\
\hline & $\begin{array}{l}\text { Негативные сопутствующие эмоции от вызванных неудобств в процессе } \\
\text { оказания услуги }\end{array}$ \\
\hline \multirow{2}{*}{$\begin{array}{l}\text { Не очень } \\
\text { часто }\end{array}$} & Получение недостоверной информации \\
\hline & Неправильный диагноз, метод лечения \\
\hline \multirow{5}{*}{ Редко } & Переплата за бренд \\
\hline & $\begin{array}{l}\text { Неудобный поиск информации о медицинском центре, врачах, персонале, } \\
\text { оказываемых услугах }\end{array}$ \\
\hline & Недополучение необходимого лечения \\
\hline & Долгий путь до медицинского центра \\
\hline & Отсутствие сопутствующих услуг \\
\hline \multirow{3}{*}{ Очень редко } & Смена лечащего врача/персонала \\
\hline & Затянувшееся обследование/лечение \\
\hline & Существенные затраты на проезд до медицинского центра \\
\hline
\end{tabular}

Источник: составлено автором

В общей сложности выделено 98 атрибутов потребительской ценности медицинской услуги.

В результате реализации следующего этапа исследования, все атрибуты выгод были сгруппированы по таким видам, как функциональные, ценовые, сервисные и эмоциональные, а атрибуты затрат - по материальным, временным, эмоциональным, физическим, рискам.

На третьем этапе атрибуты потребительской ценности медицинской услуги были соотнесены с элементами комплекса маркетинга 7Р.

В табл. 4 и 5 представлен результат второго и третьего этапов исследования отдельно по атрибутам выгод и атрибутам затрат потребительской ценности медицинской услуги соответственно. 
Атрибуты потребительской ценности медицинской услуги

в соответствии с выгодами потребителей, соотнесённые с элементами комплекса маркетинга 7 Р с видами (группами) атрибутов

\begin{tabular}{|c|c|c|c|c|c|c|}
\hline \multirow[b]{2}{*}{$7 \mathbf{P}$} & \multirow[b]{2}{*}{ No } & \multirow[b]{2}{*}{ Выгоды потребителей } & \multicolumn{4}{|c|}{$\begin{array}{c}\text { Виды } \\
\text { атрибутов }\end{array}$} \\
\hline & & & 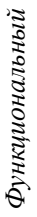 & 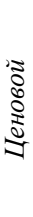 & 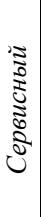 & 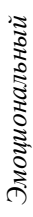 \\
\hline 1 & 2 & 3 & 4 & 5 & 6 & 7 \\
\hline \multirow{8}{*}{ 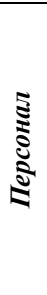 } & 1 & Аккуратный, ухоженный внешний вид сотрудников, единая форма у персонала & & & + & \\
\hline & 2 & Вежливость персонала, доброжелательность, спокойная реакция & & & & + \\
\hline & 3 & $\begin{array}{l}\text { Внимание к пациентам (предупредительность, участие в проблемах клиентов, } \\
\text { индивидуальный подход) }\end{array}$ & & & & + \\
\hline & 4 & Конкретный врач, к которому есть желание попасть на приём & + & & & \\
\hline & 5 & Наличие профессионального опыта у врача, стажа работы & + & & & \\
\hline & 6 & Приветливость, улыбчивость администраторов & & & & + \\
\hline & 7 & Уровень квалификации, профессионализм врача & + & & & \\
\hline & 8 & Уровень квалификации, профессионализм среднего медицинского персонала & + & & & \\
\hline \multirow{15}{*}{$\stackrel{\Xi}{3}$} & 9 & Возможность вызова врача на дом & + & & & \\
\hline & 10 & Возможность обслуживания и взрослых, и детей & + & & & \\
\hline & 11 & Дистанционные консультации после приема (по телефону, WhatsApp и пр.) & + & & & \\
\hline & 12 & Доступность (получение услуг в удобное время) & & & + & \\
\hline & 13 & Комплексность услуги (приём, анализы и пр. в одном месте) & + & & & \\
\hline & 14 & Наличие дневного стационара & + & & & \\
\hline & 15 & Наличие ночного стационара & + & & & \\
\hline & 16 & Наличие собственной лаборатории в медицинском центре & + & & & \\
\hline & 17 & Наличие современного оборудования & + & & & \\
\hline & 18 & Наличие узких специалистов & + & & & \\
\hline & 19 & $\begin{array}{l}\text { Полноценность, полнота приёма (разъяснения своих действий, выполнение всех } \\
\text { необходимых манипуляций, предоставление полной информации) }\end{array}$ & + & & & \\
\hline & 20 & $\begin{array}{l}\text { Получение желаемого результата от посещения медицинского центра (эффектив- } \\
\text { ность лечения, точность диагноза и пр.) }\end{array}$ & & & & + \\
\hline & 21 & Применение современных медицинских технологий и методов лечения & + & & & \\
\hline & 22 & $\begin{array}{l}\text { Уникальность оказываемой услуги (важно, что её предоставляют не все медицин- } \\
\text { ские центры) }\end{array}$ & + & & & \\
\hline & 23 & Широкий спектр оказываемых услуг & + & & & \\
\hline \multirow{5}{*}{$\frac{\mathfrak{a}}{0}$} & 24 & Доступная/низкая цена & & + & & \\
\hline & 25 & Дополнительные материальные выгоды (государственная поддержка, квоты) & & + & & \\
\hline & 26 & Понятная структура цены на услуги & & + & & \\
\hline & 27 & Соответствие стоимости услуг ожиданиям клиента & & + & & \\
\hline & 28 & Соответствие цены и качества & & + & & \\
\hline \multirow{11}{*}{ 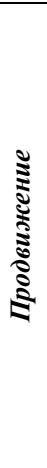 } & 29 & Бренд, положительная репутация медицинского центра & & & & + \\
\hline & 30 & $\begin{array}{l}\text { Легкость поиска информации о медицинском центре, его врачах с помощью поис- } \\
\text { ковых запросов в yandex, googl и пр. }\end{array}$ & & & & + \\
\hline & 31 & Наличие видеорекламы о медицинском центре и его врачах в сети интернет & & & & + \\
\hline & 32 & $\begin{array}{l}\text { Наличие информации не прямого рекламного характера о медицинском центре в } \\
\text { СМИ }\end{array}$ & & & & + \\
\hline & 33 & Наличие информации рекламного характера в электронных СМИ & & & & + \\
\hline & 34 & Наличие контекстной, баннерной, всплывающей рекламы в сети интернет & & & & + \\
\hline & 35 & $\begin{array}{l}\text { Наличие программы лояльности с возможностью копить бонусы, которыми можно } \\
\text { расплачиваться }\end{array}$ & & + & & \\
\hline & 36 & $\begin{array}{l}\text { Наличие программы лояльности с возможностью получать комплементы, прият- } \\
\text { ные нематериальные бонусы от медицинского центра }\end{array}$ & & & & + \\
\hline & 37 & Наличие программы лояльности с накопительной скидкой & & + & & \\
\hline & 38 & Наличие программы лояльности с фиксированной скидкой & & + & & \\
\hline & 39 & Наличие реальных отзывов клиентов в сети интернет & & & & + \\
\hline
\end{tabular}




\begin{tabular}{|c|c|c|c|c|c|c|}
\hline 1 & 2 & 3 & 4 & 5 & 6 & 7 \\
\hline & 40 & Наличие рекламных баннеров, вывесок о медицинском центре, врачах на улицах & & & & + \\
\hline & 41 & Наличие рекламы в социальных сетях, в пабликах популярных блогеров & & & & + \\
\hline & 42 & Наличие рекламы о медицинском центре, врачах на телевидении, на радио & & & & + \\
\hline & 43 & $\begin{array}{l}\text { Наличие рекламы о медицинском центре, его врачах, приходящей на электронную } \\
\text { почту }\end{array}$ & & & & + \\
\hline & 44 & Наличие удобного сайта у медицинского центра & & & + & \\
\hline & 45 & Наличие, удобство, функциональность мобильного приложения & & & + & \\
\hline & 46 & $\begin{array}{l}\text { Проведение акций, мероприятий, специальные предложения для клиентов (благо- } \\
\text { творительные акции, тематические вечеринки, праздники, утренники для детей и } \\
\text { пр.) }\end{array}$ & & & & + \\
\hline & 47 & Сарафанное радио (рекомендации родственников, друзей, знакомых) & & & & + \\
\hline \multirow{12}{*}{ 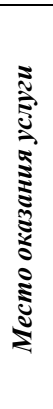 } & 48 & Длительный период работы медицинского центра на рынке & & & & + \\
\hline & 49 & Многопрофильность медицинского центра & & & + & \\
\hline & 50 & Наличие парковки & & & + & \\
\hline & 51 & Наличие специализации медицинского центра по виду оказываемых услуг & + & & & \\
\hline & 52 & Несколько медицинских центров под одним брендом (сеть) & & & + & \\
\hline & 53 & Развитая инфраструктура вблизи медицинского центра & & & + & \\
\hline & 54 & Расположение вблизи остановок общественного транспорта & & & + & \\
\hline & 55 & Удобная, понятная навигация по территории медицинского центра & & & + & \\
\hline & 56 & Удобное расположение медицинского центра в центральных районах города & & & + & \\
\hline & 57 & Удобное расположение медицинского центра вблизи дома/работы & & & + & \\
\hline & 58 & Удобный подъезд к медицинскому центру & & & + & \\
\hline & 59 & Удобный режим и график работы медицинского центра & & & + & \\
\hline \multirow{13}{*}{ 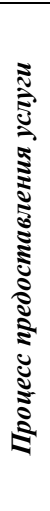 } & 60 & Возможность влиять на характеристики оказываемых услуг & & & + & \\
\hline & 61 & Гарантии безопасности предоставляемых услуг & & & + & \\
\hline & 62 & Готовность медицинского центра учитывать мнения и пожелания клиентов & & & + & \\
\hline & 63 & $\begin{array}{l}\text { Грамотное управление медицинским центром руководством (отсутствие видимых } \\
\text { проблем) }\end{array}$ & & & + & \\
\hline & 64 & $\begin{array}{l}\text { Использование элементов дополненной и виртуальной реальности при оказании } \\
\text { услуг (ЗД очки, видеосимуляторы и пр.) }\end{array}$ & + & & & \\
\hline & 65 & Наличие нескольких способов оплаты (включая безналичный расчёт) & & & + & \\
\hline & 66 & Приём по времени (отсутствие очереди) & & & + & \\
\hline & 67 & Скорость и качество постановки диагноза & + & & & \\
\hline & 68 & Скорость предоставления услуги (обследования/анализа) & + & & & \\
\hline & 69 & Удалённые консультации (получение услуги дистанционно) & + & & & \\
\hline & 70 & Удобство записи на прием (по телефону, через интернет-сайт и пр.) & & & + & \\
\hline & 71 & $\begin{array}{l}\text { Хорошо организованная работа Call-центра (оперативность, компетентность, веж- } \\
\text { ливость при ответах на звонки и сообщения) }\end{array}$ & & & + & \\
\hline & 72 & Юридическая и информационная поддержка клиентов & & & + & \\
\hline \multirow{9}{*}{ 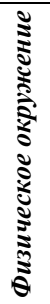 } & 73 & Возможность перекусить & & & + & \\
\hline & 74 & Доступ к питьевой воде & & & + & \\
\hline & 75 & Комфортные места ожидания, удобная мебель & & & & + \\
\hline & 76 & Красивое оформление/дизайн помещений & & & & + \\
\hline & 77 & Наличие детской комнаты & & & + & \\
\hline & 78 & Наличие музыкального сопровождения & & & & + \\
\hline & 79 & Приятный запах, отсутствие запаха больницы & & & & + \\
\hline & 80 & Приятный интерьер & & & + & \\
\hline & 81 & Уровень чистоты помещений & & & + & \\
\hline
\end{tabular}

Источник: составлено автором

Данные, представленные в табл. 4 и 5, свидетельствуют о существенной особенности атрибутивных характеристик потребительской ценности медицинской услуги: выгоды, получаемые потребителями, соотносятся с одной из четырёх выделенных групп атрибутов (функциональными, ценовыми, сервисными, эмоциональными), в то время, как определённые атрибутивные характеристики затрат потребителей могут быть одновременно соотнесены с 
несколькими различными группами атрибутов (материальными, временными, эмоциональными, физическими, рисками).

Таблица 5

Атрибуты характеристики потребительской ценности медицинской услуги в соответствии с затратами потребителей, соотнесённые

с элементами комплекса маркетинга 7Р и с видами (группами) атрибутов

\begin{tabular}{|c|c|c|c|c|c|c|}
\hline \multirow[b]{2}{*}{$\begin{array}{c}\text { Элементы } \\
\text { комплекса } \\
\text { маркетинга } \\
7 \text { P }\end{array}$} & \multirow[b]{2}{*}{ Затраты потребителей } & \multicolumn{5}{|c|}{$\begin{array}{c}\text { Виды } \\
\text { атрибутов }\end{array}$} \\
\hline & & 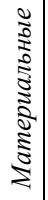 & 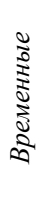 & 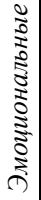 & 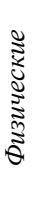 & 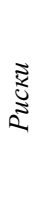 \\
\hline \multirow{2}{*}{ Персонал } & Отрицательные эмоции от взаимодействия с персоналом & & + & + & & \\
\hline & Смена лечащего врача/персонала & & + & + & & + \\
\hline \multirow{3}{*}{ Услуга } & Недополучение необходимого лечения & & & & + & + \\
\hline & Неправильный диагноз, метод лечения & & & & + & + \\
\hline & Затянувшееся обследование/лечение & & + & + & & \\
\hline \multirow{3}{*}{ Цена } & Завышенная стоимость услуг & + & & & & \\
\hline & Переплата за дополнительные ненужные услуги & + & + & & & + \\
\hline & Переплата за бренд & + & & & & \\
\hline \multirow[t]{2}{*}{ Продвижение } & $\begin{array}{l}\text { Неудобный поиск информации о медицинском центре, врачах, } \\
\text { персонале, оказываемых услугах }\end{array}$ & & + & + & + & \\
\hline & Получение недостоверной информации & & & + & & + \\
\hline \multirow{3}{*}{$\begin{array}{l}\text { Место оказа- } \\
\text { ния услуги }\end{array}$} & Долгий путь до медицинского центра & & + & & + & \\
\hline & Существенные затраты на проезд до медицинского центра & + & & & & \\
\hline & Отсутствие возможности комплексного обслуживания & & + & & & + \\
\hline \multirow{2}{*}{$\begin{array}{c}\text { Процесс пре- } \\
\text { доставления } \\
\text { услуги } \\
\end{array}$} & $\begin{array}{l}\text { Негативные сопутствующие эмоции от вызванных неудобств в } \\
\text { процессе оказания услуги }\end{array}$ & & & + & & \\
\hline & Длительное ожидание & & + & + & & \\
\hline \multirow{2}{*}{$\begin{array}{l}\text { Физическое } \\
\text { окружение }\end{array}$} & Дискомфорт от нахождения в медицинском центре & & & + & + & \\
\hline & Отсутствие сопутствующих услуг & & + & + & + & \\
\hline
\end{tabular}

Источник: составлено автором

Деление всех атрибутов потребительской ценности медицинских услуг по элементам комплекса маркетинга 7Р и по их видам даёт возможность определить значимость факторов, проводить анализ в соответствии с целями дальнейшего исследования.

На заключительном этапе, в ходе проведения интервью с экспертами, необходимо было уточнить, и, возможно, скорректировать, дополнить получившийся список атрибутов потребительской ценности.

Было опрошено 12 специалистов - экспертов в различных областях медицины, являющихся сотрудниками медицинского центра/центров. Отбор экспертов строился по принципам, представленным в табл. 6.

С разрешения экспертов, проводилась аудиозапись интервью. Вопросы задавались в ходе свободного диалога, но в соответствии с гайдом. Основные моменты сразу фиксировались в опросном листе. В результате опроса была достигнута теоретическая насыщенность. Анализ производился с использование компьютерной программы QDA Miner: подсчитывалось упоминание каждого атрибута потребительской ценности медицинской услуги по заданным кодам. 
Критерии отбора экспертов для проведения глубинного интервью

\begin{tabular}{|c|l|}
\hline Критерий & \multicolumn{1}{|c|}{ Описание } \\
\hline $\begin{array}{c}\text { Место работы } \\
\text { эксперта }\end{array}$ & $\begin{array}{l}\text { Многопрофильный медицинский центр, оказывающий услуги на коммерче- } \\
\text { ской основе взрослым или взрослым и детям. Преимущественно коммерческие } \\
\text { медицинские центры. }\end{array}$ \\
\hline Должность эксперта & $\begin{array}{l}\text { Руководитель в области маркетинга, управления медицинским центром, взаи- } \\
\text { модействия с потребителями. }\end{array}$ \\
\hline $\begin{array}{c}\text { Местонахождение } \\
\text { эксперта }\end{array}$ & $\begin{array}{l}\text { В рамках территории, обеспечивающей возможность личной встречи интер- } \\
\text { вьюера для проведения интервью. }\end{array}$ \\
\hline
\end{tabular}

Источник: составлено автором

Результаты интервью экспертов представлены в табл. 7 и 8.

Таблий 7

Атрибутивные характеристики потребительской ценности медицинской услуги

в соответствии с выгодами потребителей, выделенные по результатам интервью с экспертами

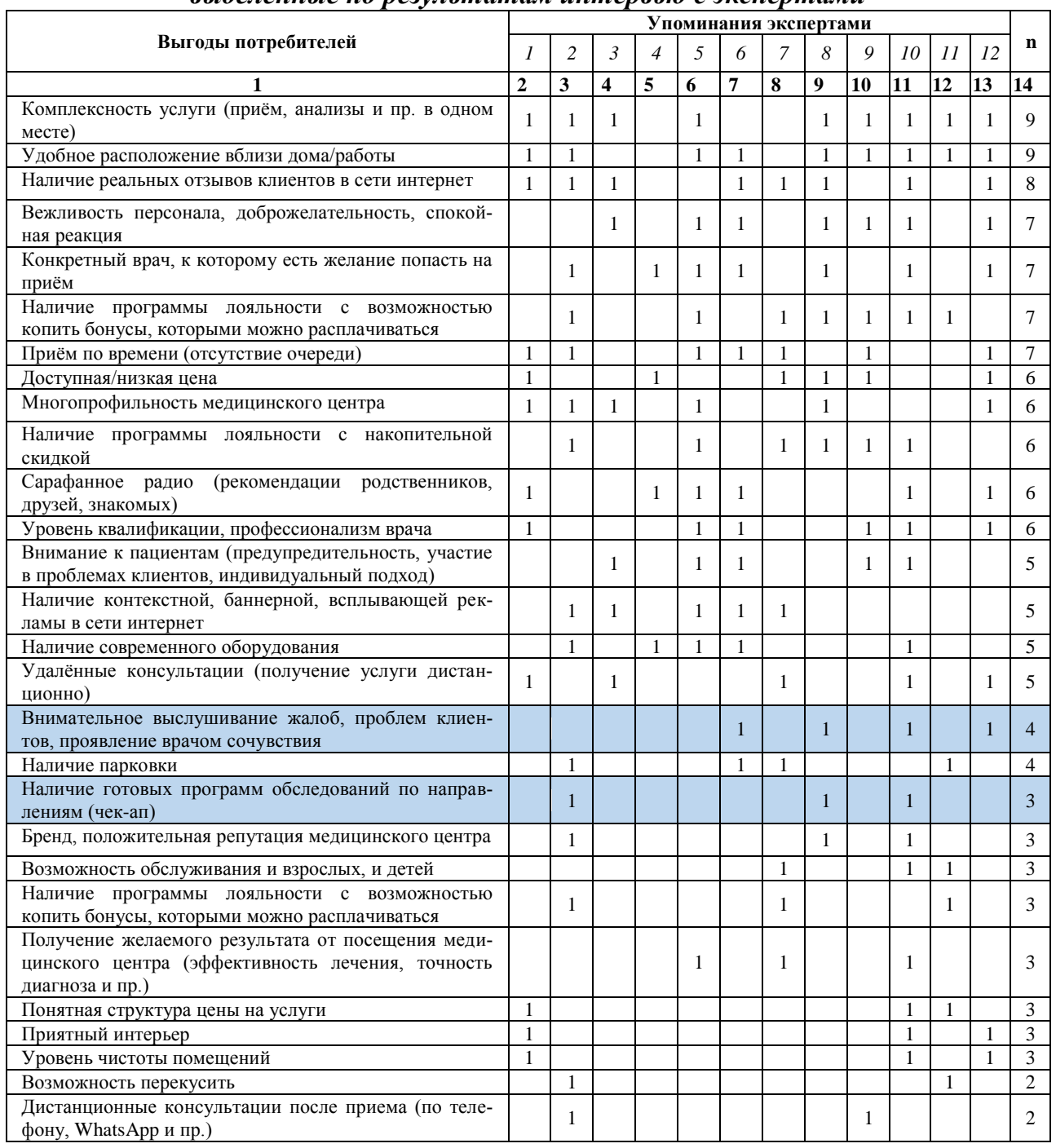




\begin{tabular}{|c|c|c|c|c|c|c|c|c|c|c|c|c|c|}
\hline 1 & 2 & 3 & 4 & 5 & 6 & 7 & 8 & 9 & 10 & 11 & 12 & 13 & 14 \\
\hline $\begin{array}{l}\text { Длительный период работы медицинского центра на } \\
\text { рынке }\end{array}$ & & & & & & & & & & 1 & 1 & & 2 \\
\hline Доступ к питьевой воде & & 1 & & & & & & & & 1 & & & 2 \\
\hline Комфортные места ожидания, удобная мебель & & & & & 1 & & 1 & & & & & & 2 \\
\hline Наличие детской комнаты & & & & & & & 1 & & & & 1 & & 2 \\
\hline $\begin{array}{l}\text { Наличие информации не прямого рекламного характе- } \\
\text { ра о медицинском центре в СМИ }\end{array}$ & & & & & & & 1 & & & 1 & & & 2 \\
\hline Наличие нескольких входов/выходов & & 1 & & & & 1 & & & & & & & 2 \\
\hline $\begin{array}{lll}\text { Наличие программы лояльности с } \text { фиксированной } \\
\text { скидкой }\end{array}$ & & & & 1 & & & & & & & & 1 & 2 \\
\hline $\begin{array}{l}\text { Наличие профессионального опыта у врача, стажа } \\
\text { работы }\end{array}$ & & & & & & & 1 & & & & & 1 & 2 \\
\hline Наличие удобного сайта у медицинского центра & & & & & & & & & & 1 & 1 & & 2 \\
\hline $\begin{array}{l}\text { Несколько медицинских центров под одним брендом } \\
\text { (сеть) }\end{array}$ & & 1 & & & & & & & & & 1 & & 2 \\
\hline $\begin{array}{l}\text { Преемственность в оказания услуги (обслуживание } \\
\text { нескольких поколений членов семьи) }\end{array}$ & & & & & & & & & & 1 & 1 & & 2 \\
\hline Приветливость, улыбчивость администраторов & & & & & & & & 1 & & 1 & & & 2 \\
\hline Приятный запах, отсутствие запаха больницы & & & & & & 1 & & & & & 1 & & 2 \\
\hline $\begin{array}{l}\text { Проведение акций, мероприятий, специальные пред- } \\
\text { ложения для клиентов (благотворительные акции, } \\
\text { тематические вечеринки, праздники, утренники для } \\
\text { детей и пр.) }\end{array}$ & & & & & & & 1 & & & 1 & & & 2 \\
\hline Развитая инфраструктура вблизи медицинского центра & & & & & & 1 & 1 & & & & & & 2 \\
\hline $\begin{array}{llll}\begin{array}{l}\text { Скорость предоставления } \\
\text { ния/анализа) }\end{array} & \text { услуги } & \text { (обследова- } \\
\end{array}$ & 1 & & & & & & & 1 & & & & & 2 \\
\hline Тематическое украшение интерьера к праздникам & & & & & & 1 & & & & 1 & & & 2 \\
\hline $\begin{array}{l}\text { Удобное расположение медицинского центра в цен- } \\
\text { тральных районах города }\end{array}$ & & 1 & & & 1 & & & & & & & & 2 \\
\hline $\begin{array}{l}\text { Удобство записи на прием (по телефону, через интер- } \\
\text { нет-сайт и пр.) }\end{array}$ & 1 & & & & 1 & & & & & & & & 2 \\
\hline Аккуратный, ухоженный внешний вид сотрудников & & & & & & & & & & 1 & & & 1 \\
\hline Доступность (получение услуг в удобное время) & & & & & & & 1 & & & & & & 1 \\
\hline $\begin{array}{l}\text { Наличие видеорекламы о медицинском центре и его } \\
\text { врачах в сети интернет }\end{array}$ & & & 1 & & & & & & & & & & 1 \\
\hline $\begin{array}{l}\text { Наличие нескольких способов оплаты (включая безна- } \\
\text { личный расчёт) }\end{array}$ & & & & & & 1 & & & & & & & 1 \\
\hline $\begin{array}{l}\text { Наличие рекламных баннеров, вывесок о медицинском } \\
\text { центре, врачах на улицах }\end{array}$ & & & & 1 & & & & & & & & & 1 \\
\hline
\end{tabular}

Примечание: $n$ - частота упоминаемости

Источник: составлено автором

Таблица 8

Атрибутивные характеристики потребительской ценности медицинской услуги в соответствии с затратами потребителей, выделенные по результатам интервью с экспертами

\begin{tabular}{|c|c|c|c|c|c|c|c|c|c|c|c|c|c|}
\hline \multirow{2}{*}{ Затраты потребителей } & \multicolumn{12}{|c|}{ Эксперт } & \multirow{2}{*}{ n } \\
\hline & 1 & 2 & 3 & 4 & 5 & 6 & 7 & 8 & 9 & 10 & 11 & 12 & \\
\hline Долгий путь до медицинского центра & 1 & 1 & & & 1 & 1 & & 1 & 1 & 1 & 1 & 1 & 9 \\
\hline $\begin{array}{l}\text { Отсутствие возможности комплексного обслужива- } \\
\text { ния }\end{array}$ & 1 & 1 & 1 & & 1 & & & 1 & 1 & 1 & 1 & 1 & 9 \\
\hline Длительное ожидание & 1 & 1 & & & 1 & 1 & 1 & 1 & 1 & & & 1 & 8 \\
\hline Завышенная стоимость услуг & 1 & & & 1 & & & 1 & 1 & 1 & & & 1 & 6 \\
\hline $\begin{array}{l}\text { Отрицательные эмоции от взаимодействия с персо- } \\
\text { налом }\end{array}$ & & & 1 & & & & & 1 & & 1 & & & 3 \\
\hline Переплата за дополнительные ненужные услуги & 1 & & & & & & & & & 1 & 1 & & 3 \\
\hline Дискомфорт от нахождения в медицинском центре & & & & & 1 & & 1 & & & & & & 2 \\
\hline $\begin{array}{l}\text { Негативные сопутствующие эмоции у потребителя от } \\
\text { вызванных неудобств в процессе оказания услуги }\end{array}$ & & & & & & & 1 & 1 & & & & & 2 \\
\hline Отсутствие сопутствующих услуг & & & & & & & & & & 1 & & & 1 \\
\hline
\end{tabular}

Примечание: $n$ - частота упоминаемости

Источник: составлено автором 
Определены наиболее часто упоминаемые атрибуты потребительской ценности медицинской услуги по выгодам. Первые 12 атрибутов из табл. 3 вспомнили более половины экспертов. Обозначены 5 новых атрибутов, которые не были найдены с помощью контент-анализа (выделены цветом в табл. 7). Из 81 атрибута, которые были определены на первом этапе исследования, 29 атрибутов не были упомянуты экспертами в ходе глубинного интервью.

Также обозначены атрибуты потребительской ценности медицинской услуги, касающиеся затрат потребителя.

Эксперты чаще всего упоминали 4 атрибута потребительской ценности по затратам. Не было предложено ни одного нового атрибута потребительской ценности, который не был бы выявлен ранее в ходе контент-анализа. Эксперты упомянули 9 атрибутов по затратам из 17 имеющихся после контент-анализа.

Мы выделили спорные моменты, по которым у экспертов возникали противоречивые точки зрения (табл. 9).

Таблий 9

Противоречивые точки зрения экспертов на значимость некоторых атрибутов потребительской ценности медицинской услуги

\begin{tabular}{|c|c|c|}
\hline \multirow{2}{*}{$\begin{array}{c}\text { Характеристика } \\
\text { атрибута }\end{array}$} & \multicolumn{2}{|c|}{ Аргументы экспертов в зависимости от занимаемой позиции } \\
\hline & «3A» & «ПРОТИВ» \\
\hline $\begin{array}{c}\text { Для потребителей } \\
\text { важна низкая цена } \\
\text { на медицинские } \\
\text { услуги. }\end{array}$ & Потребители хотят сэкономить. & $\begin{array}{l}\text { Медицинские центры не должны занижать } \\
\text { цену на услуги: себестоимость оказания ме- } \\
\text { дицинских услуг высока. } \\
\text { Цена может иметь важное значение в случае, } \\
\text { если медицинский центр выбирает опреде- } \\
\text { лённую специализацию, например, делает } \\
\text { акцент на проведении медицинских комиссий. } \\
\text { Качественные услуги не могут быть оказаны } \\
\text { по низкой цене. } \\
\text { Потребителям не важны материальные выго- } \\
\text { ды, они обращают внимание на другие пара- } \\
\text { метры. }\end{array}$ \\
\hline $\begin{array}{c}\text { Важно, чтобы в } \\
\text { медицинском } \\
\text { центре была точка } \\
\text { общественного } \\
\text { питания, где по- } \\
\text { требители могли } \\
\text { бы перекусить. }\end{array}$ & $\begin{array}{l}\text { Дополнительный фактор удобства } \\
\text { нахождения в медицинском центре. } \\
\text { Голодные клиенты с большей веро- } \\
\text { ятностью могут остаться неудовле- } \\
\text { творёнными после посещения меди- } \\
\text { цинского центра. }\end{array}$ & $\begin{array}{l}\text { Клиенты не должны находиться в ожидании } \\
\text { приёма, и времени на приём пищи, у них, } \\
\text { соответственно, также не будет. } \\
\text { Медицинские центры должны оказывать } \\
\text { профильную услугу - лечить, людей, а не } \\
\text { кормить их. При необходимости, поесть } \\
\text { можно в близлежащих заведениях обществен- } \\
\text { ного питания. }\end{array}$ \\
\hline
\end{tabular}

Источник: составлено автором

Выявив наличие противоречивых атрибутов потребительской ценности медицинской услуги, мы также столкнулись со сложностью в понимании конкретного значения некоторых из них. Как в процессе контент-анализа, так 
и при проведении интервью с экспертами, мы установили, что имеются достаточно размытые характеристики, например, «индивидуальный подход к клиентам», «качество медицинской услуги», «внимание к пациентам», «общение с клиентами». В тех случаях, когда характеристики очень обобщённые, мы их не учитывали при анализе, а продолжали поиск более узких характеристик. Так, несмотря на то, что и в процессе контент-анализа, и при проведении интервью, часто встречался термин «качество медицинской услуги», данная характеристика не рассматривается нами как отдельный атрибут потребительской ценности медицинской услуги, т.к. точное описание, того, что именно потребители подразумевают под качеством медицинской услуги, отсутствует. При этом качество представляет собой набор характеристик и является структурным элементом потребительской ценности. Поэтому в дальнейшем исследовании учитываются атрибуты, характеризующие качество медицинской услуги.

\section{Заключение}

Автором предложен методический подход, который позволяет определить атрибуты потребительской ценности медицинских услуг. Данный подход подразумевает реализацию четырёх этапов, направленных на формирование перечня атрибутов.

В результате проведённого исследования выделены конкретные атрибуты потребительской ценности медицинской услуги.

Подсчёт частоты упоминаемости конкретных атрибутов в профильных источниках, а также экспертами из медицинской сферы, позволил предположить о наибольшей значимости в структуре потребительской ценности тех атрибутов, упоминание которых встречается наиболее часто. Подтвердить или опровергнуть данную гипотезу могут результаты дальнейших исследований, в частности, опроса потребителей. Но уже на данном этапе можно выделить атрибуты потребительской ценности медицинской услуги, которые наиболее часто встречаются среди 103 выявленных атрибутов. Коммерческие медицинские центры смогут их использовать в операционной деятельности, оттачивая и совершенствуя характеристики, имеющие ценность для клиентов.

Представленное исследование дало существенный задел для дальнейшего определения тех атрибутов, которые могут иметь наибольшее значение для различных категорий потребителей и, соответственно, могут отличаться в зависимости от формата медицинской организации.

Результаты исследования будут полезны для осуществления оценки потребительской ценности услуг, оказываемых коммерческими медицинскими центрами. Данная оценка необходима для формирования оптимального набора атрибутивных характеристик и выявления аспектов, имеющих особенную значимость для потребителей.

Обозначенные противоречивые точки зрения экспертов на значимость некоторых атрибутов потребительской ценности медицинской услуги (в отношении низкой цены на услуги, наличия детской комнаты и точки общественного питания) помогают оперировать выделенными плюсами в случае, как наличия, так и отсутствия данных атрибутов при оказании медицинской ус- 
луги в зависимости о целевой аудитории коммерческих медицинских центров и конкретных видов оказываемых услуг.

Перечень из 103 атрибутов потребительской ценности медицинских услуг, включающий атрибуты выгод, и затрат, формирует целостное представление о значимых для клиентов аспектах при выборе того или иного медицинского центра. Так как все выделенные атрибуты сгруппированы по видам и соотнесены с элементами комплекса маркетинга 7Р, полученные результаты позволяют медицинским центрам обозначить аспекты, обладающие наибольшим значением для потребителей, воздействуя в большей или меньшей степени на функциональные, ценовые, сервисные, эмоциональные характеристики медицинской услуги, а также на затраты, которые несут потребители материальные, временные, эмоциональные, физические, риски.

\section{Список источников / References}

1. Котлер Ф. 300 ключевых вопросов маркетинга: отвечает Котлер. Москва, ЗАО «Олимп-бизнес, 2006. 224 с. [Kotler F. 300 klyuchevykh voprosov marketinga: otvechaet Kotler. Moskva, ZAO «Olimp-biznes, 2006 [300 key marketing questions: Kotler answers]. Moscow, Olymp-Business Publ., 2006. 224 p.]

2. Definition of Marketing - American MaketingAssotiation. Avalaible at: http://www.marketingpower.com/AboutAMA/Pages/DefinitionofMarketing.aspx

3. Levitt T. Marketing Success through Differentiation - of Anything, Harvard Business Review, January-February 1980.

4. Park C.W., Jaworski B.J., Maclnnis D.J. Strategic brand concept-image management. The Journal of Marketing, 1986. pp. 135-145.

5. Sheth J.N., Newmen B.I, Gross B.l. Consumption Values and Market Choices: Theory and Applications, Cincinaty, OH: South Western Publishing Company, 1991.

6. Sweeney, J.C., \&Soutar, G.N. Consumer perceived value: The development of a multiple item scale. Journal of retailing, 2001, no. 77 (2), pp. 203-220. Available at: http://dx.doi.org/10.1016/S0022-4359(01)00041-0

7. Gallarza G.M., Gil-Saura I., Holbrook M.B. The value of value: Furthe excursions on the meaning and role of customer value Journal of Consumer Behaviour, J. Consumer Behav, 2011, no. 10, pp. 179-191.

8. Котлер Ф. Основы маркетинга: пер с англ. - 2-е европ. изд. Москва, Издательский дом «Вильямс», 2002. 944 с. [Kotler F. Osnovy marketinga: Per s angl. - 2-e evrop. izd. [Marketing Basics]. Moscow, Williams Publ., 2002. 944 p.]

9. Джоббер Д. Принципы и практика маркетинга: пер. с англ.: Уч. пос. Москва, Издательский дом «Вильямс», 2000. 688 с. [Dzhobber D. Printsipy i praktika marketinga: Per. s angl.: Uch. pos. [Principles and Practice of Marketing]. Moscow, Williams Publ., 2000. 688 p.]

10. Brock S.J., Colgate M. Customer valuecreation. Journal of Marketing Theory and Practice, 2007, no. 15 (1), pp. 7-23.

11. Wang Y., Po Lo, Chi R., \& Yang Y. An integrated framework for customer value and customer-relationship management performance: a customer-based perspective from China. Managing Service Quality: An International Journal, 2004, no. 14 (2/3), pp. 169-182. Available at: http://dx.doi.org/10.1108/09604520410528590

12. Бест Р. Маркетинг от потребителя. Москва, Манн, Иванов и Фебер, 2011. 760 с. [Best R. Marketing ot potrebitelya [Consumer marketing]. Moscow, Mann, Ivanov \& Feber Publ., 2011. 760 p.] 
13. Slater S.F. Developing a customer value-based theory of the firm. Journal of the Academy of Marketing Science, 1997. pp. 162-167.

14. Дубинина М.А. Формирование ценности бренда молочной продукции региона. Дисс. канд. экон. наук. Ростов-на-Дону., 2010. 175 с. [Dubinina M.A. Formirovanie tsennosti brenda molochnoi produktsii regiona [The formation of the brand value of dairy products in the region]. Diss. kand. ekon. nauk. Rostov-on-Don., 2010. 175 p.]

15. Зверева А.В. Подходы к повышению потребительской ценности ИТ-услуг на примере облачных услуг системной интеграции, Москва, 2015. [Zvereva A.V. Podkhody k povysheniyu potrebitel'skoi tsennosti IT-uslug na primere oblachnykh uslug sistemnoi integratsii [Approaches to increasing the consumer value of ITservices using the example of cloud systems integration services]. Moscow, 2015.]

16. Юдаев А.В. Управление межфирменным взаимодействием на основе концепции цепочки создания ценности (на примере фармацевтического рынка). Дисс. канд. экон. наук. Москва, 2011. 166 с. [Yudaev A.V. Upravlenie mezhfirmennym vzaimodeistviem na osnove kontseptsii tsepochki sozdaniya tsennosti (na primere farmatsevticheskogo rynka) [Intercompany interaction management based on the concept of a value chain (on the example of the pharmaceutical market)]. Diss. kand. ekon. nauk. Moscow, 2011. 166 p.]

17. Kahneman D., Amos T. Prospect Theory: An Analysis of Decision under Risk. Econometrica, XVLII, 1979, pp. 263-291.

18. Канеман Д. Думай медленно... решай быстро. Москва, АСТ, 2014. 653 с. [Kaneman, D. Dumai medlenno... reshai bistro [Think slowly ... decide quickly]. Moscow, AST Publ., 2014. 653 p.]

19. Бычкова Н.В., Окольнишникова И.Ю., Кузменко Ю.Г. Обзор методов оценки потребительской ценности кинотеатральных услуг. Вестник ЮУрГУ. Серия «Экономика и менеджмент», 2015, т. 9, №4, сс. 140-148. [Bychkova N.V., Okol'nishnikova I.Yu., Kuzmenko Yu.G. Obzor metodov otsenki potrebitel'skoi tsennosti kinoteatral'nykh uslug [Review of methods for assessing the consumer value of cinema services]. Vestnik YuUrGU. Seriya "Ekonomika i menedzhment" = Bulletin of SUSU. Series "Economics and Management", 2015, vol. 9, №4, pp. 140-148.]

\section{Сведения об авторе / About author}

Сологуб Елена Владимировна, аспирант, Школа экономики и менеджмента, Дальневосточный федеральный университет. 690091 Россия, г. Владивосток, ул. Суханова, д. 8.

E-mail: sologub.ev@dvfu.ru

Elena V. Sologub, Postgraduate Student, School of Economics and Management, Far Eastern Federal University. 8 Suhanova str., Vladivostok, Russia 690091.E-mail: sologub.ev@dvfu.ru 